\title{
Studies on the Effect of Water Stress on Root Traits in Green Gram Cultivars
}

\begin{abstract}
Background: Green gram is one of the important pulse crops of chief protein source, with ability to fix nitrogen. Erratic rainfall, while it's grown as rainfed crop, leads to the yield loss due to water stress. Plant root system architecture is plastic and is important sink of photosynthates. In general, the ability of plants to change its root distribution for exploiting water deeper in soil profiles can be an important mechanism to avoid soil water stress. Identification of genotypes based on root traits under water stress conditions will aid in development of drought tolerant varieties for yield exploitation.

Methods: The experiment was conducted during Rabi, 2018-19 with five green gram varieties as main treatment and irrigation intervals as sub treatments in three replications in factorial RBD in root structures. Observations were recorded on root parameters at flowering stage. The root structures were dismantled during flowering stage and all the plants removed from the soil without damaging the roots by using water with jet pump. Five representative samples were collected under different stress level. Root studies were performed with Delta T automatic root scanner. The SPAD chlorophyll meter was used to measure canopy leaves and average of the three readings was taken as SCMR value.

Result: The present study results on root studies revealed that genotype, MGG-295 recorded highest mean plant height under three stress conditions and same genotype also produced longer root length under mild water stress conditions, higher SCMR values under non-stress and mild stress. Genotype, MGG-347 recorded highest root diameter under non- stress and mild stress. MGG-385 produced highest root length under control and severe stresses, highest SCMR values under severe stress, root dry weight under mild and severe water stresses and total plant dry weight under control and mild stress. MGG-360 recorded higher shoot fresh weight under severe stress and same genotype also recorded significant superior values for total root area under mild and severe water stress and root tip count under non-stress, mild stress and severe stress. MGG-351 recorded shoot fresh weight under non stress and mild stress situations and the same genotype recorded highest values for root diameter and total plant dry weight under severe stress. The identified genotypes can be used as water stress resistant genotypes in future drought proof breeding programmes.
\end{abstract}

Key words: Cultivars, Greengram, Root traits, Water stress.

\section{INTRODUCTION}

Drought stress is one of the most key aspects for crop yield losses in recent years. Pulses on account of their short duration and ability to thrive better than other crops under harsh climate and fragile ecosystems on one hand and the national agenda to achieve household nutritional security on the other hand. Among the various tresses prevailing, water stress is the major constraint in all pulse growing regions of India, particularly in rainfed farming systems under arid (precipitation/potential evapotranspiration < 0.2 ) and semi-arid $(0.2<\mathrm{P} / \mathrm{PET}<0.5)$ environments and in sub-humid $(0.5<$ P/PET < 0.75) and humid areas (P/PET > 0.75). Among the factors influencing plant growth, water availability has a great impact on root distribution patterns. A dry soil surface with high water stress often 'forces' roots to grow deep into the soil profile, where water is more available (Adiku et al., 1996). Subsequent research showed that root system, among many other mechanisms of water stress tolerance, was one of the major traits conferring seed yield advantage.

The screening followed by selections of desirable genotypes is important for successful breeding to develop the elite lines having drought tolerance capacity (Feller, 2006, Saidaiah et al., 2021). Different morphological, physiological and biochemical parameters have been
Department of Crop Physiology, College of Agriculture, Professor Jayashankar Telangana State Agricultural University, Palem509 215, Telangana, India.

Corresponding Author: Geetha Amarapalli, Department of Crop Physiology, College of Agriculture, Professor Jayashankar Telangana State Agricultural University, Palem-509 215, Telangana, India. Email: geethagri_100@yahoo.co.in

How to cite this article: Amarapalli, G. (2022). Studies on the Effect of Water Stress on Root Traits in Green Gram Cultivars. Legume Research. DOI: 10.18805/LR-4630.

Submitted: 07-04-2021 Accepted: 05-01-2022 Online: 11-02-2022

established for drought stress tolerance assessment in plants based on proline accumulation, leaf area index, yield component etc (Alderfasi et al., 2017; Swathi et al., 2017). Plant root system architecture is plastic as well as dynamic and is important sink of photosynthates (Pietola and Alakukku, 2005). In general, the ability of plants to change its root distribution for exploiting water deeper in soil profiles can be an important mechanism to avoid soil water stress (Bandyopadhyay and Mallick, 2003). Among morphological traits, the maximum root length per unit volume, root diameter and root: shoot dry weight ratio is the traits 
responsible for evaluation for high quality of information for water stress tolerance mechanisms (Khan et al., 2010). Kirchhof et al. (2000) while studying with the root distribution pattern in mungbean, observed that root length was closely related to soil strength and depth, associated largely with water content and bulk density changes with depth. Root length density and root surface area possess a definite relationship with crop phonological stages. Liu et al. 2011 observed root growth of various pulse crops at late flowering stage while large differences in distribution pattern were revealed among crop species. Rooting depth, extent and timing of root growth played a major role in the adaptation of chickpea to terminal drought stress (Serraj et al., 2004), however, had no direct relationship between the seed yield and the root depth or the root biomass. In general, the root length density values of pulse crops are lower than various cereal crops in the plough layer (Siddique et al., 2001). Very few information is available regarding distribution patterns of roots for pulses. The effect of drought is recorded in various pulse crops. Production of blackgram is adversely affected by drought that reduce yield (Pandey et al., 2014). Reduced root length due to water stress. It impairs root cell development, nutrient uptake and affects photosynthesis; hence, affect root elongation (Yohan et al., 2018). Deep and dense root system display better drought tolerance by extracting water from deeper layers (Parameshwarappa et al., 2012). Plants subjected to drought at yearly reproductive stage produced lowest number of pods per plant and yield (Yohan et al., 2018). The genotypes with more root length, root and pod dry matter, pods per plant and pods per cluster under both irrigated as well as stress conditions, denotes the ability of these genotypes in sustaining the higher root length and absorb the water from deeper layers of soils (Yohan et al., 2018). The genotypes which perform better under lower water potential are suitable for growing under water deficit condition (Kaur et al., 2017). Hence, an attempt was made to study the behaviour of root traits in different green gram cultivars under various levels of water stress.

\section{MATERIALS AND METHODS}

An experiment was conducted during Rabi, 2018-19 (Second fortnight of October to first fortnight of January, 2019) at Regional Agricultural Research Station, Professor Jayashankar Telangana State Agricultural University, Palem, Nagarkurnool District. The planting material comprised of five green gram varieties viz., MGG-347, MGG-359, MGG360, MGG-385, MGG-351 and MGG-295 as main treatments and water stress levels are taken as sub treatments in three replications in factorial $R B D$ in root structures. Sub treatment irrigation intervals included control (irrigation given at regular intervals): mild stress (with holding irrigation for 10 days at vegetative stage) and severe stress (with holding irrigation for 20 days at vegetative stage). The root structure was a tank, constructed with cement block measuring of 18 metre length $\times 1.2$ metre height and $1.5 \mathrm{~m}$ width and filled with red soil to represent normal field condition. The spacing followed was $30 \times 10 \mathrm{~cm}^{2}$. All the package of practices was followed to raise the healthy crop.

At flowering stage, observations were recorded on plant height, shoot fresh weight, root fresh weight, root to shoot ratio, main tap root length, total root diameter, total toot air, total number of lateral roots per plant, SPAD chlorophyll meter reading (SCMR), root dry weight and total plant dry weight. The root structures were dismantled during flowering stage or active vegetative growth stage of the crop and all the plants removed from the soil without damaging the roots by using water with jet pump. After roots have been removed from their surrounding soil environment in the laboratory or the field, a number of processing steps remain before root traits can be assessed, including washing, sorting and preserving the sample for further use. About five representative samples were collected under different stress level from the each genotype and root studies were performed with Delta T automatic root scanner. In each entry, about five plants were tagged under different stress treatment and plant height was measured from base to top. The SPAD chlorophyll meter was used to measure from top middle and bottom canopy leaves and average of the three readings was taken as SCMR value.

\section{RESULTS AND DISCUSSION}

Screening and selection of desirable genotypes for drought tolerance is the first and foremost important step in pulse breeding program (Jincya et al., 2019). Keeping the above in view, six genotypes of greengram were evaluated for root and shoot parameters under mild and severe stress conditions along with control. The results indicated significant variability among the genotypes and their interaction with various stress conditions. For the trait plant height, genotype MGG-295 showed significantly (Table 1) superiority performances in all three irrigation intervals viz., control (Non stress), mild stress, severe water stress and also in genotype $\times$ water stress interactions with the values of $40.3 \mathrm{~cm}, 32.7 \mathrm{~cm}, 31.2 \mathrm{~cm}$ and $34.7 \mathrm{~cm}$, respectively. Shoot fresh weight (g/plant) decreased with the increase in severity of water stress. The shoot fresh weight recorded significantly highest mean value in non stress treatment (8.14 g/plant), which was at par with means of mild water stress (7.46 g/plant). Among the genotypes, MGG-351 recorded highest shoot fresh weight value in control $(9.8 \mathrm{~g} /$ plant), mild stress (9.36 g/plant) and in genotypes and water stress interactions (8.37). Whereas, in severe water stress treatment, genotype MGG-385 (Fig 1) recorded highest and significantly superior value of shoot fresh weight of $6.5 \mathrm{~g} /$ plant. In arid and semi arid areas water scarcity is major limiting factor of crop production and productivity. Drought response is the outcome of different morphological, physiological and biochemical alteration triggered at molecular level. The comprehensive study on mechanism, 
responses and dynamics to limited water conditions for developing resistant lines of green gram cultivars is gaining noticeable considerations. The drought conditions during crop growth have negative impact on water balance; hence decrease the water potential of leaves (Parvin et al., 2015; Chowdhury et al., 2017). Morphological, physiological and biochemical analysis of transgenic green gram variety IPM02-03 Vr TIP-1 gene showed enhanced tolerance to drought. Growth and survival of non-transformed plant was lower than transformed plant under drought stress condition (Aparna et al., 2020).

The parameter, root fresh weight increased with the increase in severity of the water stress situations. Among, the genotypes, MGG-347 recorded highest root fresh weight value (Table 2 ) in severe stress (1.387g/plant) and genotype $x$ stress interactions. Whereas, genotype, MGG-360 recorded highest value of root fresh weight (1.35 g/plant) under mild water stress condition. The root to shoot ratio increased with the increase in severity of water stress. For the parameter root to shoot ratio, two genotypes viz., MGG360 and MGG-351 recorded highest value of 0.17 in control. The two genotypes recorded 0.217 values under severe stress and 0.178 values under genotypes $\mathrm{x}$ stress interactions. Whereas, under mild stress conditions, two genotypes MGG-359 and MGG-385 recorded highest value of 0.173 .

Root parameter is a major trait associated with soil water stress and large variations exist between crop species in terms of the association of root morphological traits and their functionality including root length or root length density, root mass, root diameter and root tips. Root length increased initially up to non-stress to mild water stress and declined in severe water stress conditions. Genotype, MGG-385 recorded highest main root length values of $25.6 \mathrm{~cm}, 30.5$ $\mathrm{cm}$ and $27.3 \mathrm{~cm}$, respectively (Table 3 ) under non-stress, severe stress and Interactions of the genotypes $\times$ stress. Whereas, under severe water stress conditions genotypes MGG-385 recorded highest value of $34.88 \mathrm{~cm}$ followed by genotype MGG-295, which recorded $3.17 \mathrm{~cm}$. The results are in accordance with the reports of Geetha et al. (2012). The genotypes with longer roots have deeper root system would allow water extraction from lower soil profiles and thus, it is expected that the plant will perform better under moisture stress. Increase in root length is an adaptive mechanism

Table 1: Effect of water stress on plant height $(\mathrm{cm})$ and shoot fresh weight ( $\mathrm{g} / \mathrm{plant})$ in green gram cultivars.

\begin{tabular}{|c|c|c|c|c|c|c|c|c|}
\hline \multirow{2}{*}{ Genotypes } & \multicolumn{3}{|c|}{ Plant height $(\mathrm{cm})$} & \multicolumn{5}{|c|}{ Shoot fresh weight (g/plant) } \\
\hline & Control & Mild stress & Severe stress & Means & Control & Mild stress & Severe stress & Means \\
\hline MGG-347 & 37.1 & 30.2 & 27.1 & 31.4 & 7.6 & 6.9 & 5.8 & 6.7 \\
\hline MGG-359 & 30.6 & 29.3 & 23.3 & 27.7 & 7.4 & 6.9 & 4.9 & 6.4 \\
\hline MGG-360 & 36.2 & 26.3 & 23.9 & 28.7 & 8.3 & 7.7 & 6.2 & 7.4 \\
\hline MGG-385 & 31.9 & 30.1 & 24.6 & 28.8 & 8 & 7.3 & 6.5 & 7.3 \\
\hline MGG-351 & 36.6 & 27.8 & 25.9 & 30.1 & 9.8 & 9.3 & 5.9 & 8.4 \\
\hline MGG-295 & 40.3 & 32.7 & 31.2 & 34.7 & 7.8 & 6.4 & 4.7 & 6.3 \\
\hline \multirow[t]{2}{*}{ Means } & 35.4 & 29.4 & 25.9 & & 8.1 & 7.4 & 5.672 & \\
\hline & C.D & $\operatorname{SE}(d)$ & $\mathrm{SE}(\mathrm{m})$ & & & C.D & $S E(d)$ & $\mathrm{SE}(\mathrm{m})$ \\
\hline Genotypes & 2.3 & 1.1 & 0.8 & & Genotypes & 0.5 & 0.2 & 0.2 \\
\hline Stresses & 1.6 & 0.8 & 0.5 & & Stresses & 0.3 & 0.1 & 0.1 \\
\hline $\mathrm{G} \times \mathrm{S}$ & 18.9 & 1.9 & 1.3 & & $\mathrm{G} \times \mathrm{S}$ & 0.8 & 0.4 & 0.3 \\
\hline
\end{tabular}

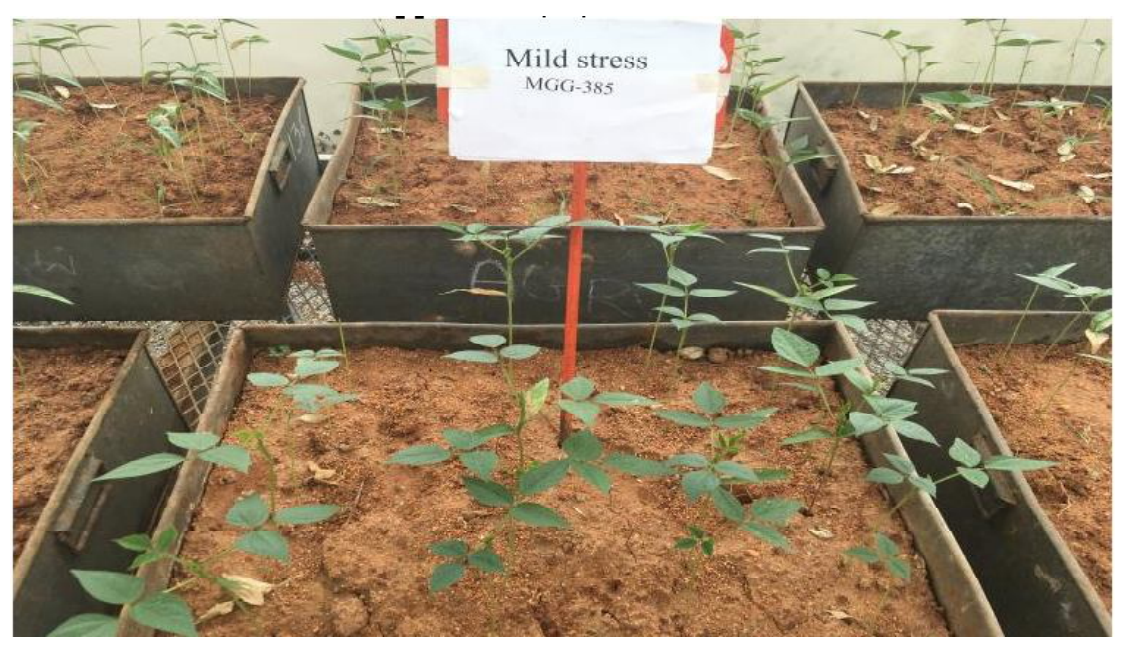

Fig 1: Performance of green gram variety MGG-385 in mild stress. 
for drought tolerant genotypes. Therefore, higher value may be used for the discrimination between drought tolerant and susceptible genotypes. Rauf and Sadqat, (2008) stated that increase in root length occurred due to higher osmotic adjustment ability of drought genotypes. Chun et al. (2005) and (Petcu and Petcu, 2006) also indicated that increase in root length occurred at expense of lateral roots.

Total root diameter declines with increase in severity of water stress. Under, non-stress conditions, genotype, MGG347 recorded highest total root diameter of $4.89 \mathrm{~mm}$ followed by MGG-360 (4.39 $\mathrm{mm}$ ) (Table 3 ) in non-stress of water. Whereas, genotype, MGG-347 recorded highest significantly superior total root diameter value of $4.39 \mathrm{~mm}$ under mild water stress and same genotype recorded highest total root diameter in genotype $x$ stress interactions $(3.99 \mathrm{~mm})$. This showed at par values of two other genotypes, MGG-360 $(3.67 \mathrm{~mm})$ and MGG-351 $(3.68 \mathrm{~mm})$. Under severe water stress, one genotype, MGG-351 recorded highest and significantly superior value $(3.13 \mathrm{~mm})$ for water stress. Root area can also be an indicator of the effects of soil strength on root growth (Qin et al. 2004). Pulse crops possess much greater root diameters than oilseeds indicating that pulse could facilitate root penetration into the soil, helping to improve soil physical properties by loosening micro pores of the soil vertically (Bengough et al., 2006).

Total number of tips which is indication of lateral roots per plant decreased with increase in severity of the water stress. Among the genotypes, MGG-295 recorded significantly superior value for lateral rootlets (102). The genotype MGG360 recorded highest number of lateral roots mild water stress and severe stress with values of 78 and 72.6. The same genotype recorded highest number of tips (75.2) in stress $\times$ genotype interactions. The number of root tips is a critical indicator of root function from water uptake to regulation of whole plant growth (Aiken and Smucker, 1996). Thus, the number of root tips is an important determinant of the plant's ability to absorb water and nutrients from the soil. Field pea had the greatest number of root tips up to late flowering stage as compared to chickpea and lentil

Table 2: Effect of water stress on root fresh weight $(\mathrm{g})$ and root to shoot ratio in green gram cultivars.

\begin{tabular}{|c|c|c|c|c|c|c|c|c|}
\hline \multirow{2}{*}{ Genotypes } & \multicolumn{4}{|c|}{ Root fresh weight $(\mathrm{g})$} & \multicolumn{4}{|c|}{ Root to shoot ratio } \\
\hline & Control & Mild stress & Severe stress & Means & Control & Mild stress & Severe stress & Means \\
\hline MGG-347 & 1.24 & 1.35 & 1.38 & 1.32 & 0.16 & 0.14 & 0.18 & 0.16 \\
\hline MGG-359 & 1.15 & 1.2 & 1.20 & 1.18 & 0.17 & 0.17 & 0.15 & 0.16 \\
\hline MGG-360 & 1.23 & 1.36 & 1.37 & 1.32 & 0.17 & 0.15 & 0.22 & 0.18 \\
\hline MGG-385 & 1.06 & 1.07 & 1.14 & 1.09 & 0.17 & 0.17 & 0.15 & 0.16 \\
\hline MGG-351 & 1.15 & 1.09 & 1.08 & 1.11 & 0.17 & 0.15 & 0.22 & 0.18 \\
\hline MGG-295 & 1.2 & 1.24 & 1.23 & 1.06 & 0.17 & 0.16 & 0.18 & 0.16 \\
\hline \multirow[t]{2}{*}{ Means } & 0.85 & 0.82 & 1.23 & 1.32 & 0.16 & 0.16 & 0.18 & 0.17 \\
\hline & C.D & $S E(d)$ & $\mathrm{SE}(\mathrm{m})$ & & & C.D & $S E(d)$ & $\mathrm{SE}(\mathrm{m})$ \\
\hline Genotypes & 0.08 & 0.04 & 0.03 & & Genotypes & 0.09 & 0.01 & 0.01 \\
\hline Stresses & 0.29 & 0.03 & 0.02 & & Stresses & 0.01 & 0.01 & 0.01 \\
\hline$G \times S$ & 0.72 & 0.07 & 0.05 & & $\mathrm{G} \times \mathrm{S}$ & 0.03 & 0.02 & 0.01 \\
\hline
\end{tabular}

Table 3: Effect of water stress on main root length $(\mathrm{cm})$, total root diameter $(\mathrm{mm})$ and total number of lateral roots per plant $(\mathrm{mm})$ in green gram cultivars.

\begin{tabular}{|c|c|c|c|c|c|c|c|c|c|c|c|c|}
\hline \multirow{2}{*}{ Genotypes } & \multicolumn{4}{|c|}{$\begin{array}{l}\text { Main root } \\
\text { length }(\mathrm{cm})\end{array}$} & \multicolumn{4}{|c|}{$\begin{array}{c}\text { Total root } \\
\text { diameter }(\mathrm{mm})\end{array}$} & \multicolumn{4}{|c|}{$\begin{array}{l}\text { Total number of lateral } \\
\text { roots per plant }(\mathrm{mm})\end{array}$} \\
\hline & Control & $\begin{array}{l}\text { Mild } \\
\text { stress }\end{array}$ & $\begin{array}{l}\text { Severe } \\
\text { stress }\end{array}$ & Means & Control & $\begin{array}{l}\text { Mild } \\
\text { stress }\end{array}$ & $\begin{array}{l}\text { Severe } \\
\text { stress }\end{array}$ & Mean & Control & $\begin{array}{l}\text { Mild } \\
\text { stress }\end{array}$ & $\begin{array}{l}\text { Severe } \\
\text { stress }\end{array}$ & Means \\
\hline MGG-347 & 14.93 & 17.57 & 19.5 & 17.33 & 4.89 & 4.39 & 2.7 & 3.99 & 68.33 & 53 & 26 & 49.11 \\
\hline MGG-359 & 23.7 & 34.83 & 22 & 26.84 & 3.18 & 2.48 & 2.65 & 2.77 & 52.67 & 45.33 & 29 & 42.33 \\
\hline MGG-360 & 22.07 & 23.23 & 19.83 & 21.71 & 4.39 & 3.25 & 2.45 & 3.36 & 85 & 78 & 62.67 & 75.22 \\
\hline MGG-385 & 25.6 & 25.8 & 30.53 & 27.31 & 1.75 & 1.94 & 2.26 & 1.99 & 61.33 & 48 & 51 & 53.44 \\
\hline MGG-351 & 22.13 & 24.5 & 20.67 & 22.43 & 4.11 & 3.8 & 3.13 & 3.68 & 78.33 & 60 & 21 & 53.11 \\
\hline MGG-295 & 16.9 & 31.67 & 26.3 & 24.96 & 3.92 & 2.64 & 2.54 & 3.03 & 102 & 64.67 & 51.33 & 72.67 \\
\hline \multirow[t]{2}{*}{ Means } & 20.89 & 26.27 & 23.14 & & 3.71 & 3.08 & 2.62 & & 74.611 & 58.18 & 40.17 & \\
\hline & C.D & $S E(d)$ & $\mathrm{SE}(\mathrm{m})$ & & & C.D & $S E(d)$ & $\mathrm{SE}(\mathrm{m})$ & & C.D & $S E(d)$ & $S E(m)$ \\
\hline Genotypes & 4.86 & 2.38 & 1.68 & & Genotypes & 0.57 & 0.28 & 0.199 & & 15.81 & 7.75 & 5.48 \\
\hline Stresses & 3.44 & 1.69 & 1.19 & & Stresses & 0.41 & 0.2 & 0.14 & & 11.18 & 5.48 & 3.87 \\
\hline$G \times S$ & $\mathrm{~N} / \mathrm{s}$ & 4.12 & 2.91 & & $G \times S$ & 0.99 & 0.49 & 0.344 & & NS & 13.42 & 9.49 \\
\hline
\end{tabular}


Studies on the Effect of Water Stress on Root Traits in Green Gram Cultivars

Table 4: Effect of water stress on SCMR and root dry weight $(\mathrm{g})$ and total plant dry weight $(\mathrm{g} / \mathrm{plant})$ in green gram cultivars.

\begin{tabular}{|c|c|c|c|c|c|c|c|c|c|c|c|c|}
\hline \multirow[b]{2}{*}{ Genotypes } & \multicolumn{4}{|c|}{ SCMR } & \multicolumn{4}{|c|}{ Root dry weight (g) } & \multicolumn{4}{|c|}{ Total plant dry weight (g/plant) } \\
\hline & Control & $\begin{array}{c}\text { Mild } \\
\text { stress }\end{array}$ & $\begin{array}{l}\text { Severe } \\
\text { stress }\end{array}$ & Means & Control & $\begin{array}{c}\text { Mild } \\
\text { stress }\end{array}$ & $\begin{array}{l}\text { Severe } \\
\text { stress }\end{array}$ & Mean & Control & $\begin{array}{c}\text { Mild } \\
\text { stress }\end{array}$ & $\begin{array}{l}\text { Severe } \\
\text { stress }\end{array}$ & Means \\
\hline MGG-347 & 39.51 & 37.16 & 34.67 & 37.11 & 0.83 & 0.62 & 0.30 & 0.59 & 10.71 & 8.94 & 4.8 & 8.15 \\
\hline MGG-359 & 38.56 & 35.73 & 31.67 & 35.32 & 0.49 & 0.7 & 0.37 & 0.52 & 9.16 & 6.85 & 4.54 & 6.85 \\
\hline MGG-360 & 42.47 & 36.97 & 35 & 38.14 & 0.61 & 0.48 & 0.42 & 0.5 & 9.66 & 7.16 & 3.12 & 6.65 \\
\hline MGG-385 & 40.29 & 37.28 & 36.33 & 37.97 & 0.54 & 0.69 & 0.77 & 0.67 & 11.38 & 11.49 & 6.17 & 9.68 \\
\hline MGG-351 & 37.61 & 37.31 & 34.67 & 36.53 & 0.85 & 0.66 & 0.58 & 0.69 & 9.23 & 7.98 & 9.01 & 8.74 \\
\hline MGG-295 & 43.26 & 37.98 & 35.33 & 38.86 & 0.37 & 0.45 & 0.37 & 0.4 & 4.93 & 3.25 & 1.98 & 3.39 \\
\hline \multirow[t]{2}{*}{ Means } & 40.28 & 37.07 & 34.61 & & 0.62 & 0.6 & 0.47 & & 9.18 & 7.61 & 4.94 & \\
\hline & C.D & $S E(d)$ & $\mathrm{SE}(\mathrm{m})$ & & C.D & $S E(d)$ & $\mathrm{SE}(\mathrm{m})$ & & C.D & $S E(d)$ & $\mathrm{SE}(\mathrm{m})$ & \\
\hline Genotypes & 1.59 & 0.78 & 0.55 & & 0.04 & 0.02 & 0.02 & & 0.46 & 0.23 & 0.16 & \\
\hline Stresses & 1.13 & 0.55 & 0.39 & & 0.03 & 0.02 & 0.01 & & 0.33 & 0.16 & 0.11 & \\
\hline $\mathrm{G} \times \mathrm{S}$ & 1.35 & 1.35 & 0.95 & & 0.08 & 0.04 & 0.03 & & 0.8 & 0.39 & 0.28 & \\
\hline
\end{tabular}

(Liu et al., 2011). Bandyopadhyay et al. (2012) observed that root tips of lentil increased with crop age under different management practices. Saima et al., 2018 reported that shoot and root weights and lengths, root length stress index, dry matter stress index (DMSI) and plant height stress index showed considerable variations under drought conditions.

SPAD chlorophyll meter reading (SCMR values) decreases with the increase in severity of the water stress as existing chlorophyll molecules degraded with onset of water stress conditions. MGG-360 recorded highest and superior value in control (42.46) for the SPAD chlorophyll meter readings (Table 4 ). Under mild stress conditions, genotype MGG-295 recorded highest value of 37.9 which was at par with MGG-351 (37.3), MGG-385 (37.28) and MGG-347 (37.16), whereas under severe water stress conditions, genotype, MGG-385 recorded significantly superior value of 36.3. In interactions of genotypes $x$ stress two genotypes, MGG-295 and MGG-385 showed significantly superior values of 38.8 and 37.9 , respectively. The parameter root dry weight decreased with the increase in severity of water stress. Among the genotypes, MGG351 recorded highest and significantly superior values of root dry weight ( $0.853 \mathrm{~g} / \mathrm{plant}$ ) followed by MGG-347 (0.827). Under mild water stress conditions, genotype, MGG-385 recorded highest root dry weight of $0.7 \mathrm{~g} / \mathrm{plant}$ followed by MGG-385 (0.693 g/plant), MGG-347 (0.623 g/plant), MGG359 (0.48 g/plant) and MGG-295 (0.45 g/plant). Under severe water stress conditions, genotypes, MGG-385 recorded highest root dry weight value of $(0.77 \mathrm{~g} / \mathrm{plant})$ followed by MGG-359 (0.37 g). Under genotypes $x$ stress interactions MGG-295 recorded highest value of root dry weight (0.697 g/plant) followed by MGG-385(0.61 g/plant). Sangakkaran et al. (2000) reported that drought tolerant mungbean diverted more carbon to roots under moisture stress. Drought stressed plants diverted significantly higher dry matter to roots and stems, while well watered plants diverted to pods and grains (Kumar and Sharma, 2009). It has also been shown that mungbean genotypes having higher root bio-mass produced higher pod (Boutraa et al., 1999). Similar to the present study, using this level of moisture stress 108 green gram genotypes were screened for their drought tolerance at seedling level using radicle length, root length stress index, germination stress index (Jincya et al., 2019).

Total plant dry weight decreased with the increase in severity of water stress (Table 4). Genotype, MGG-360 recorded highest total plant dry weight under non stress (11.83 $\mathrm{g} /$ plant) and mild stress $(11.49 \mathrm{~g} / \mathrm{plant})$ and in the genotype $\times$ stress interaction (9.68). Whereas in severe water stress genotype, MGG-385 recorded highest and significantly superior value of 9.0 (g/plant). Similar results are earlier reported by Sangakkaran et al., 2000. The variation in seedling growth characteristics was specific for genotypes under reduced water potential. Similar results were also reported in green gram and black gram (Kaur et al., 2017, Jincya et al., 2019).

\section{CONCLUSION}

The present study results revealed that genotype, MGG295 recorded highest mean plant height under three stress conditions and longer root length under mild water stress conditions, higher SCMR values under non-stress and mild stress. Genotype, MGG-347 recorded highest root diameter under non- stress and mild stress. MGG-385 for root length under control and severe stresses, SCMR values under severe stress, root dry weight under mild and severe water stresses and total plant dry weight under control and mild stress; MGG-360 for shoot fresh weight under severe stress, and significant superior values for total root area under mild and severe water stress and root tip count under non-stress, mild stress and severe stress performed well. The identified genotypes can be used as water stress resistant genotypes in future breeding programmes. The identified genotypes can be used as genetic materials in crop improvement programmes to develop climate smart green gram varieties 
as well. The selected genotypes have been observed to possess tolerance traits to withstand under drought stress and can be used for further investigations. Selection of this criteria is more economical, requires less water and easy screening larger number of germplasm at seedling stage itself. Our Research finding will helpful to the greengram breeders to providing the guidelines for cultivation of greengram varieties under moisture stress conditions in future.

\section{REFERENCES}

Adiku, S., Braddock, R. and Rose, C. (1996). Simulating growth dynamics. Environmental Software. 11: 99-103.

Aiken, R.M. and Smucker, A.J.M. (1996). Root system regulation of whole plant growth. Annual Review of Phytopathology. 34: 325-346.

Alderfasi, A.A., Alzarqaa, A.A., Al-Yahya, F.A., Roushdy, S.S., Dawabah, A.A., Alhammad, B.A. (2017). Effect of combined biotic and abiotic stress on some physiological aspects and antioxidant enzymatic activity in mungbean (Vigna radiata L.). African Journal of Agricultural Research. 12: 700-705.

Aparna, P.P., Kailash, C.S., Simachal, S. and Prem, N.J. (2020). Morphological, Physiological and Biochemical evaluation of transgenic green gram [Vigna radiata (L.) Wilczek] for drought tolerance. International Journal of Chemical Studies. 8(3): 1139-1147.

Bandyopadhyay, P.K. (2012). Mitigating abiotic stresses and enhancing resource use efficiency in pulses in rice fallows through innovative resource conservation practices at ICAR Research Complex, Umium, Meghalaya.

Bandyopadhyay, P.K. and Mallick, S. (2003). Estimation of root distribution and water uptake pattern of wheat under shallow water table condition in Damodar Valley irrigation command area. Journal of Indian Society of Soil Science. 51: 103-110.

Bengough, A.G., Bransby, M.F., Hans, J., Mckenn, S.J., Roberts, T.J. and Valentine, T.A. (2006). Root responses to soil physical conditions, growth dynamics from field to cell. Journal of Experimental Biology. 57: 437-447.

Boutraa, T., Iqbal, M.J. and Sanders, F.E. (1999). Can we improve the tolerance of Phaseolus vulgaris cultivars to low soil phosphorus by selecting for greater root biomass. Journal of Experimental Botany. 4: 4-39

Chowdhury, J.A., Karim, M.A., Khaliq, Q.A., Ahmed, A.U., Mondol, A.M. (2017). Effect of drought stress on water relation traits of four soybean genotypes. SAARC Journal of Agriculture. 15: 163-175.

Chun, L., Guohuo, M., Jiansheng, L., Fanjun, C. and Fusuo, Z. (2005). Genetic analysis of maize root characteristics in response to low nitrogen stress. Plant and Soil. 276: 369-382.

Feller, U. (2006). Stomatal opening at elevated temperature: An underestimated regulatory mechanism. General and Applied Plant Physiology. 32: 19-31.

Geetha, A., Suresh, J. and Saidaiah, P. (2012). Study on response of sunflower (Helianthus annus L.) genotypes for root and yield characters under water stress. Current Biotica. 6(1): 32-41.
Jincya, M., V., Babu Rajendra Prasad, A.P., Jeyakumara, A., Senthila and Manivannan, N. (2019). Evaluation of green gram genotypes for drought tolerance by PEG (polyethylene glycol) induced drought stress at seedling stage. DOI: 10.18805/LR-4149.

Kaur, R., Kaur, J. and Bains, T.S. (2017). Screening of mungbean genotypes for drought tolerance using different water potential levels. Journal of Advanced Agricultural Technologies. 4(2).

Khan, H.R., Paull, J.G., Siddique, K.H.M. and Stoddard, F.L. (2010). Fababean breeding for drought-affected environments: A physiological and agronomic perspective. Field Crops Research. 115: 279-286.

Kirchhof, G.,So, H.B., Adisarwanto, T., Utomo, W.H., Priyono, S., Prastowo, B., Basir, M., Lando, T.M., Subandi, Dacanay, E.V., Tan-Elicano, D. and Sanidad, W.B. (2000). Growth and yield response of grain legumes to different soil management practices after rainfed lowland rice. Soil and Tillage Research. 56: 51-66.

Kumar, A. and Sharma, K.D. (2009). Physiological responses and dry matter partitioning of summer mungbean (Vigna radiata L.) genotypes subjected to drought conditions. Journal of Agronomy and Crop Science. 95: 270-277.

Liu Liping, Gan, Yantai., Bueckert, Rosalind and Rees, Ken Van. (2011). Rooting systems of oilseed and pulse crops I: Temporal growth patterns across the plant developmental periods. Field Crops Research. 122: 256-263.

Pandey, S., Ror, S. and Chakraborty, D. (2014). Analysis of biochemical responses in Vigna mungo varieties subjected to drought stress and possible amelioration. International Journal Scientific Research in Agricultural Sciences. 1(1): 6-15.

Parameshwarappa, S.G., Salimath, P.M., Upadhyaya, H.D., Patil, S.S., Kajjidoni, S.T., Patil, B.C and Narayana, Y.D. (2012). Variation in root characters of selected drought tolerant accessions of chickpea (Cicer arietinum L.) grown under terminal drought. Karnataka Journal of Agricultural Science. 25(3): 389-391.

Parvin, S., Javadi, T. and Ghaderi, N. (2015). Proline, protein, Rwc and MSI contents affected by paclobutrazol and water deficit treatments in strawberry cv. Paros. Cercetari Agronomice in Moldova. 48(1): 107-114.

Petcu, G.H. and Petcu, E. (2006). Effect of cultural practices and fertilizers on sunflower yields in long term experiments. Helia. 29(44): 135-144.

Pietola, L. and Alakukku, L. (2005). Root growth dynamics and biomass input by Nordic annual field crops. Agriculture Ecosystem and Environment. 108: 135-144.

Qin, R.J., Stamp, P. and Richner, W. (2004). Impact of tillage on root systems of winter wheat. Agronomy Journal. 96: 1523-1530.

Rauf, S. and Sadaqat, H.A. (2008). Effect of varied water regimes on root length, dry matter partitioning and endogenous plant growth regulators in sunflower (Helianthus anuus L.). Journal of Plant Interactions. 2(1): 41-51.

Saidaiah, P., Pandravada, S.R., Sivaraj, N., Geetha, A., Lingaiah, N. (2021). Understanding of yield stability in jack bean (Canavalia ensiformis L.) genotypes using AMMI and GGE bi-plot models. Legume Research. https://doi.org/ 10.18805/ LR-4548. 
Saima, S., Li, G. and Wu, G. (2018). Effects of drought stress on hybrids of Vigna radiata at germination stage. Biologia Futura. 69: 481-492.

Sangakkaran, U.R., Frehner, M. and Nosberger, J. (2000). Effect of soil moisture and potassium fertilizer on shoot water potential, photosynthesis and partitioning of carbon in mungbean and cowpea. Journal of Agronomy and Crop Science. 185: 201-207.

Serraj, R., Krishnamurthy, L., Kashiwagi, J., Kumar, J., Chandra, S. and Crouch, J.H. (2004). Variation in root traits of chickpea (Cicer arietinum L.) grown under terminal drought. Field Crops Research. 88: 115-127.
Siddiqui, Z.A., Iqbal, A. and Mahmood, I. (2001). Effects of Pseudomonas fluorescens and fertilizers on the reproduction of Meloidogyne incognita and growth of tomato. Applied Soil Ecology. 16: 179-185.

Swathi, L., Reddy, D.M., Sudhakar, P. and Vineela, V. (2017). Screening of mungbean [Vigna radiata (L.) Wilczek] genotypes against water stress mediated through polyethylene glycol. International Journal of Current Microbiology and Applied Science. 6: 2524-2531.

Yohan, Y., Sudhakar, P., Umamahesh, V., Mohan Reddy, D. and Sumathi, V. (2018). Influence of moisture stress on root traits and yield components of mungbean genotypes. Int. J. Curr. Microbiol. App. Sci. 7(12): 2867-2877. 